ISSN : 2303-1514 | E-ISSN : 2598-5949

DOI : http://dx.doi.org/10.33578/jpfkip.v10i1.8119

https://primary.ejournal.unri.ac.id/index.php/JPFKIP

\title{
PROJECT BASED LEARNING IN INSTRUCTIONAL MEDIA COURSE FOR THE DESIGN OF LEARNING MEDIA AT ELEMENTARY SCHOOLS
}

\author{
Siti Quratul Ain ${ }^{1}$, Elpri Darta Putra ${ }^{2}$, Eva Astuti Mulyani ${ }^{3}$ \\ ${ }^{1,2}$ PGSD, FKIP Universitas Islam Riau, Pekanbaru, Indonesia \\ ${ }^{3}$ PGSD, FKIP Universitas Riau, Pekanbaru, Indonesia \\ ${ }^{1}$ quratulain@edu.uir.ac.id, ${ }^{2}$ elpri.dp@edu.uir.ac.id, ${ }^{3}$ eva.astuti@lecturer.unri.ac.id
}

\section{PEMBELAJARAN BERBASIS PROYEK PADA MATA KULIAH MEDIA \\ PEMBELAJARAN DALAM PERANCANGAN MEDIA BELAJAR DI SEKOLAH DASAR}

\begin{tabular}{|c|c|}
\hline ARTICLE HISTORY & ABSTRACT \\
\hline $\begin{array}{l}\text { Submitted: } \\
05 \text { September } 2020 \\
05^{\text {th }} \text { september } 2020\end{array}$ & $\begin{array}{l}\text { Abstract: The purpose of this study was to explain project-based learning activities on } \\
\text { instructional media courses for the design of learning media at elementary schools. This study } \\
\text { also aimed to determine the students' perceptions towards project-based learning in } \\
\text { instructional media courses. This study was a quantitative descriptive study using literature } \\
\text { study and surveys. One of learning activities in media course which used project-based } \\
\text { learning model was designing visual, audio-visual, and multimedia learning media. The stages } \\
\text { in designing the learning media were started from analyzing basic competencies in one subject, } \\
\text { making a learning media framework, creating the design results, and finally presenting how to } \\
\text { use the learning media as well as publishing to Google Classroom. The results revealed that } \\
\text { students' perceptions towards project-based learning in learning media courses based on each } \\
\text { indicator were as follow. The percentage for the indicator of student and lecturer interactions } \\
\text { was } 82.53 \% \text { (good); for the indicator of students' learning interests was } 80.66 \%(g o o d) ; \text { for the } \\
\text { indicator of competency in understanding teaching materials was } 88.53 \% \text { (good); for the } \\
\text { indicator of competency to think critically, effectively, and efficiently was } 88.66 \% \text { (good); for } \\
\text { the indicator of time management competence was } 80.26 \text { (good); for the indicator of students } \\
\text { learning outcomes was } 88.40 \% \text { (good), and for the appropriateness of project-based learning } \\
\text { application with subject characteristics was } 91.20 \% \text { (very good). }\end{array}$ \\
\hline
\end{tabular}

Accepted:

02 Januari 2021

02 $2^{\text {nd }}$ January 2021

Published:

18 Februari 2021

$18^{\text {th }}$ February 2021
Keywords : project based learning, students' perception, designing learning media

\begin{abstract}
Abstrak: Tujuan penelitian ini adalah untuk menjelaskan bentuk kegiatan pembelajaran berbasis proyek pada mata kuliah media pembelajaran di sekolah dasar dalam perancangan media belajar di SD. Selain itu untuk mengetahui gambaran persepsi mahasiswa terhadap pembelajaran berbasis proyek pada mata kuliah media pembelajaran. Jenis penelitian ini merupakan penelitian deskriptif kuantitatif yang menggunakan studi pustaka dan survey. Salah satu bentuk kegiatan mata kuliah media pembelajaran dengan menggunakan model pembelajaran berbasis proyek adalah pembuatan media belajar visual, audio visual dan multimedia dengan tahapan, perancangan media belajar mulai dari menganalisis kompetensi dasar pada satu mata pelajaran. Kemudian membuat kerangka media pembelajaran, membuat hasil rancangan, dan terakhir mempresentasikan cara menggunakan media pembelajaran serta mempublikasikan ke google classroom. Persepsi mahasiswa terhadap pembelajaran berbasis proyek pada mata kuliah media pembelajaran berdasarkan indikator Interaksi mahasiswa dan dosen $82.53 \%$, (baik), minat belajar mahasiswa $80.66 \%$, ( baik), kompetensi memahami materi ajar $88.53 \%$, (baik), kompetensi berfikir kritis, efektif dan efesien $88.66 \%$ (baik), kompetensi manajemen waktu 80.26 (baik), hasil belajar mahasiswa $88.40 \%$, (baik), kesesuaian penerapan pembelajaran berbasis proyek dengan karakteristik mata kuliah 91.20\%, (sangat baik)
\end{abstract}

Kata kunci: Pembelajaran berbasis proyek, persepsi mahasiswa, rancangan media belajar 


\section{CITATION}

Ain. S. Q., Putra, E. D., \& Mulyani, E. A. (2021). Project Based Learning in Instructional Media Course for the Design of Learning Media at Elementary Schools. Primary: Jurnal Pendidikan Guru Sekolah Dasar, 10 (1), 43 - 50 DOI: http://dx.doi.org/10.33578/jpfkip.v10i1.8119.

\section{PENDAHULUAN}

Pendidikan merupakan sarana penting untuk meningkatkan kualitas sumber daya manusia (SDM) dalam menjamin sebuah kemajuan suatu bangsa dan negara. Peningkatan kualitas sumber daya manusia dapat direalisasikan dalam menghadapi persaingan global sekarang ini. Melalui sistem pendidikan yang sejalan dengan itu Tirtarahardja \& La Sulo (2010:227) mengemukakan bahwa "pendidikan mempunyai tugas menyiapkan sumber daya manusia untuk pembangunan." Oleh karena itu, penigkatan kualitas sumber daya manusia sejak dini adalah prioritas utama dalam memajukan suatu bangsa dan negara. Sehubungan dengan itu, dalam UndangUndang Sistem Pendidikan Nasional No.20 pasal 3 tahun 2003 yang menyatakan bahwa:

Mencerdaskan kehidupan bangsa dan mengembangkan kehidupan manusia Indonesia seutuhnya, yaitu manusia yang beriman dan bertakwa kepada Tuhan Yang Maha Esa dan berbudi pekerti luhur, memiliki pengetahuan dan keterampilan, kesatuan jasmani dan rohani, kepribadian yang mantap dan mandiri serta rasa tanggung jawab kemasyarakatan dan kebangsaan. Tentu saja dalam memajukan sumber daya manusia dapat meningkatkan kualitas pendidikan suatu bangsa dan negara maka dari itu, kualitas pendidikan menjadi prioritas utama suatu bangsa dan negara. Salah satu yang berpengaruh dalam meningkatkan sumber daya manusia yaitu pendidik dalam hal ini adalah guru yang berperan penting dan memiliki tanggung jawab dalam mengembang tugas begitu juga mengatasi masalah -masalah yang muncul.

Kurikulum saat ini menghendaki keaktifan siswa dalam belajar, dimana guru tidak saja melakukan kegiatan belajar mengajar tetapi guru berfikir bagaimana proses transfer ilmu itu terjadi, yakni bagaimana siswa dapat memahami dan mengaplikasikan materi ajar yang disampaikan.

Sampai saat ini, pembelajaran yang terlaksana di sekolah dasar umumnya berbasis pada behaviorisme dengan penekanan pada transfer pengetahuan dan latihan. Dimana dalam transfer pengetahuan penggunaan media pembelajaran yang kurang interaktif dapat menyebabkan kurangnya motivasi siswa dalam belajar. Motivasi belajar akan tercipta apabila ditunjang oleh beberapa faktor, yaitu faktor eksternal dan faktor internal. Faktor internal adalah faktor yang terjadi dalam diri seseorang, sedangkan faktor eksternal adalah faktor motivasi yang muncul dari bahan ajar, guru, model, metode, media dan lingkungan belajar (Allannasir: 2016).

Empat alasan rasional mengapa media pembelajaran penting untuk digunakan dalam pembelajaran, yaitu: (1) meningkatkan mutu pembelajaran, (2) tuntutan paradigma baru, (3) kebutuhan pasar, dan (4) visi pendidikan global ( Asyhar. 2011:12)

Program Studi Pendidikan Sekolah Dasar Universitas Islam Riau memiliki tujuan menyiapkan lulusan yang mampu berdaya saing sebagai guru pendidikan sekolah dasar. Salah satu mata kuliah yang mendukung tercapainya tujuan tersebut adalah adanya mata kuliah media pembelajaran. Mahasiswa program studi pendidikan guru sekolah dasar diharapkan mempunyai gambaran, pemahaman, keterampilan dan kemampuan mengenai media pembelajaran yang sesuai diterapkan di sekolah dasar. Media pembelajaran tersebut adalah media yang bersifat tradisional dan modern. Oleh karena itu, setelah menempuh mata kuliah ini para 
mahasiswa diharapkan mampu memahami penggunaan media pembelajaran, mampu memanfaatkan media pembelajaran dan mampu menciptakan berbagai macam media pembelajaran yang sesuai dengan karakteristik siswa sekolah dasar.

Pelaksanaan perkuliahan atau pembelajaran mata kuliah media pembelajaran ini menggunakan model berbasis proyek. Hal ini sesuai dengan tujuan perkuliahan yaitu menghasilkan mahasiswa yang mampu memanfaatkan, menggunakan dan menciptakan media pembelajaran sebagai penunjang proses belajar mengajar.

$$
\text { Pembelajaran berbasis proyek }
$$

memiliki kelebihan antara lain (1) meningkatkan hasil belajar dan motivasi siswa, (2) mendorong siswa untuk kreatif dan mandiri dalam menghasilkan produk, (3) memberikan pengalaman siswa untuk membangun pengetahuannya sendiri, (4) meningkatkan kemampuan siswa untuk mengkomunikasikan produk (Baidowi : 2015) . Model pembelajaran proyek dapat meningkatkan kemampuan pemecahan masalah dan kecerdasan emosional (Karina:2014). Oleh karena itu, diharapkan pembelajaran berbasis proyek dapat menjadi sebuah pemecahan masalah bagaimana mahasiswa tidak hanya memahami dan memanfaatkan media pembelajaran, tetapi dapat merancang media belajar yang kreatif dan inovatif dalam peningkatan motivasi belajar khususnya disekolah dasar.

Berdasarkan latar belakang diatas, maka rumusan masalah yang dikemukakan adalah (1)Bagaimana pembelajaran berbasis proyek pada mata kuliah media pembelajaran di SD? (2)Bagaimana respon mahasiswa terhadap pembelajaran berbasis proyek pada mata kuliah media pembelajaran di SD?

\section{Pembelajaran berbasis proyek}

Pembelajaran berbasis proyek merupakan model pembelajaran yang memberikan kesempatan kepada pendidik untuk mengelola pembelajaran di kelas dengan melibatkan kerja proyeknya. Melalui pembelajaran kerja proyek, kreativitas dan motivasi siswa dapat meningkat. Metode ini dipandang sebagai bentuk open-ended contextual activity-learning, dan merupakan bagian dari proses pembelajaran yang memberi penekanan pada pemecahan masalah sebagai suatu usaha kolaboratif, yang dilakukan dalam proses pembelajaran pada periode tertentu (Made, 2014:144)

Pembelajaran berbasis proyek memiliki potensi besar untuk memberikan pengalaman belajar yang lebih menarik dan menyenangkan bagi siswa. Menurut Buck institute for education sebagaimana dikutip oleh Wena, pembelajaran berbasis proyek memiliki karakteristik sebagai berikut:

a. Siswa membuat keputusan dan membuat kerangka kerja

b. Terdapat masalah yang pemecahannya tidak ditentukan sebelumnya

c. Siswa merancang proses untuk mencapai hasil

d. Siswa bertanggung jawab mendapatkan dan mengelola informasi yang dikumpulkan

e. Siswa melakukan evaluasi secara kontinu.

f. Siswa secara teratur melihat kembali apa yang mereka kerjakan

g. Hasil akhir berupa produk dan evaluasi kualitas

h. Atmosfir kelas memberi toleransi kesalahan dan perubahan.

Berdasarkan beberapa karakteristik diatas, pembelajaran berbasis proyek menjadi model pembelajaran yang dapat membangun kemandirian dan kreatifitas siswa. Selain itu, melalui pembelajaran berbasis proyek siswa dilatih untuk terbiasa bertanggung jawab mewujudkan apa yang direncanakan sesuai dengan minat dan kemampuannya.

Langkah-langkah pembelajaran berbasis proyek menurut kementerian Pendidikan dan kebudayaan (2013: 212) langkah-langkah operasional atau pelaksanaan pembelajaran berbasis proyek dalam kurikulum 2013 digambarkan sebagai berikut. 


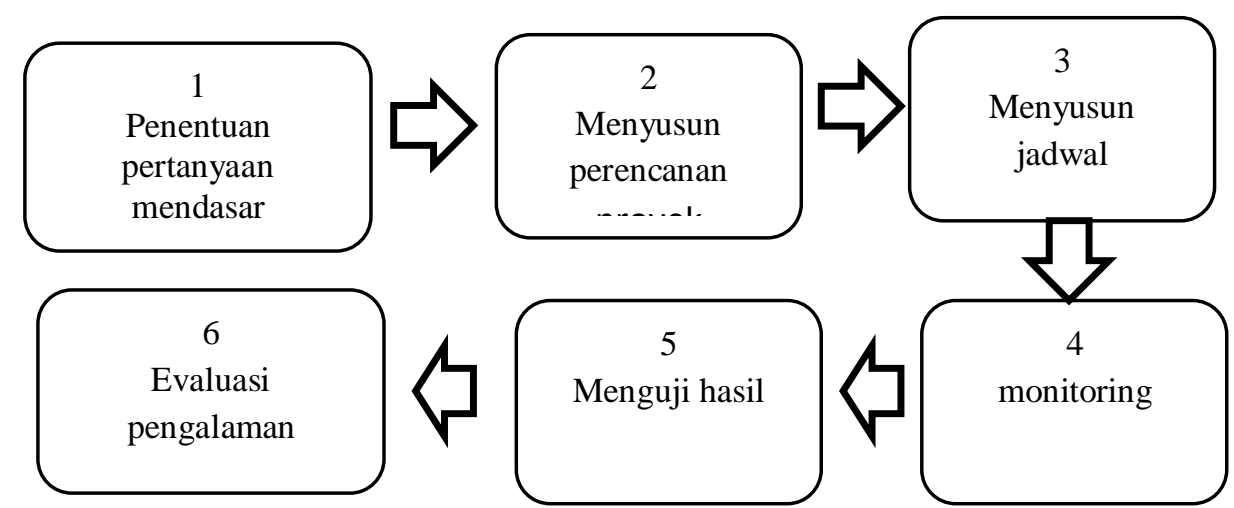

Gambar 1. Langkah-Langkah Pelaksanaan Pembelajaran Berbasis Proyek

\section{METODE PENELITIAN}

Metode penelitian ini adalah deskriptif kuantitatif. Jenis penelitian ini merupakan penelitian yang menggunakan metode studi pustaka dan survey. Penelitian. Penelitian deskriptif adalah penelitian dengan metode untuk menggambarkan suatu hasil penelitian. Namun, hasil gambaran tersebut tidak digunakan untuk membuat kesimpulan yang lebih umum (Sugiyono: 2008) penelitian dilakukan pada semester genap di bulan Februari- Juni 2020.

Penelitian dilaksanakan dalam mata kuliah media pembelajaran di SD prodi PGSD FKIP UIR. Pengambilan sampel penelitian dengan teknik purposive sampling. Peneliti memutuskan bahwa subjek penelitian ini adalah mahasiswa semester 4 kelas A. yang berjumlah 50 orang. Alasan pemilihan kelas 4/A dikarenakan semua mahasiswa pada kelas 4/A mengambil mata kuliah media pembelajaran di SD. Penelitian ini dilaksanakan dari bulan Februari-Juni 2019. Data berupa kegiatan yang dilakukan menggunakan pembelajaran berbasis proyek. Peran peneliti dalam penelitian adalah sebagai praktisi, penganalisis data dan pelapor sebagai hasil tindakan penelitian. Selain itu, peneliti juga dibantu oleh teman sejawat yang bertindak sebagai observer dan mengambil catatan lapangan yang dibutuhkan.

Teknik pengumpulan data berupa non tes dengan instrumen yang digunakan adalah angket dan dokumentasi. Angket ditujukan untuk mengukur persepsi mahasiswa terhadap model pembelajaran berbasis proyek. Penyusunan instrumen dilakukan dengan menyusun kisi-kisi instrumen kemudian diuraikan menjadi butir pernyataan yang kemudian diukur menggunakan skala likert 15. Data kemudian dianalisis menggunakan kriteria sebagai berikut.

$\mathrm{DP}=\frac{\Sigma x}{N x \sum \text { item } x \text { Skala tertinggi }} \times 100 \%$

Keterangan:

DP = Derajat Pencapaian (persentase)

$\mathrm{N} \quad=$ Jumlah sampel

$\Sigma \mathrm{X}=$ Total Skor

$\Sigma$ Item $=$ Jumlah item pertanyaan

Setelah melakukan perhitungan maka dilanjutkan dengan menentukan persentase kategori derajat pencapaian seperti pada Tabel 1 berikut ini untuk setiap indicator. 


\section{Tabel 1. Kategori Derajat Pencapaian}

\begin{tabular}{ccc}
\hline No & \% pencapaian & Kategori \\
\hline 1 & $90-100 \%$ & Sangat baik \\
2 & $80-89 \%$ & Baik \\
3 & $65-79 \%$ & Cukup \\
4 & $55-64 \%$ & Kurang \\
5 & $0-54 \%$ & Tidak baik \\
\hline
\end{tabular}

\section{HASIL DAN PEMBAHASAN}

Mata kuliah media pembelajaran di SD termasuk mata kuliah yang wajib diambil oleh mahasiswa PGSD FKIP UIR. Mata kuliah ini terdiri dari 2 SKS dan berlangsung selama 16 kali pertemuan. Dalam pelaksanaannya mata kuliah ini membahas tentang teori yang berkaitan dengan media pembelajaran di SD selama 9 kali pertemuan tatap muka. Kemudian dilanjutkan dengan perancangan, pelaksanaan dan mempresentasikan hasil dari

Sebagai model pembelajaran, pembelajaran berbasis proyek memiliki tahapan- tahapan. Tahapan yang digunakan seperti yang sudah dicantumkan pada gambar 1. Kemudian dijelaskan secara terperinci pada gambar 2 produk yang sudah dibuat oleh mahasiswa PGSD. Kegiatan pembelajaran dilaksanakan sebelum diberlakukannya kebijakan study for home karena merebaknya pandemi covid 19. Pada kegiatan perancangan, pelaksanaan dan mempresentasikan hasil dari produk, peneliti mengumpulkan data menggunakan lembar observasi.

\section{Deskripsi bentuk pembelajaran berbasis proyek.}

Proyek yang digunakan dalam mata kuliah ini adalah proyek media pembelajaran visual, audio visual dan multimedia. Berikut dijelaskan salah satu tahapan proyek pembuatan media

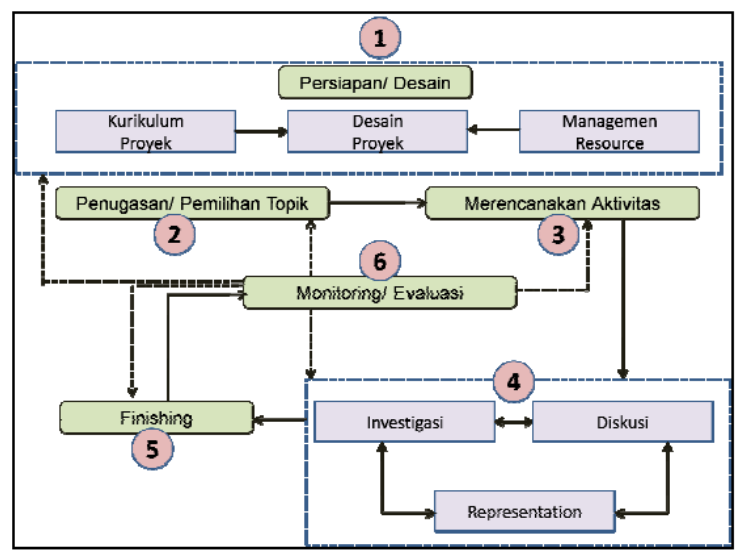

Sumber: (Hutasuhut, 2010:201)

Gambar 2. Diagram Tahapan dalam Model Pembelajaran Berbasis Proyek

Tahap 1 yaitu persiapan. Dosen dan mahasiswa menentukan masalah, dalam hal ini adalah media yang mudah dibuat dalam waktu yang singkat tetapi dapat dimanfaatkan bagi siswa. Mahasiswa dibagi menjadi 3 kelompok besar yaitu untuk menentukan jenis media yang akan dibuat yaitu visual, audio visual dan multimedia. Kemudian dari masing-masing kelompok jenis media tersebut, mahasiswa diberikan kewenangan untuk menentukan media yang akan dibuat untuk satu mata pelajaran atau berdasarkan tema pada pembelajaran tematik. 
Tahap 2 yaitu penugasan / pemilihan topic. Mahasiswa diberikan kesempatan untuk memilih topik atau materi yang akan digunakan dalam pembuatan proyek.

Tahap 3 yaitu mahasiswa merencanakan aktivitas, membuat rancangan dalam pembuatan proyek.

Tahap 4, yaitu diskusi dan investigasi masalah serta merepresentasikan rancangan yang sudah dibuat

Tahap 5 dilakukan finishing atau pembuatan proyek. Kemudian proyek yang sudah dibuat di kirim baik foto maupun vidionya di google classroom. Tahap terakhir adalah tahap monitoring atau evaluasi terhadap hasil produk.

Proyek media pembelajaran dipilih karena sebagai calon guru mahasiswa dituntut untuk kreatif dan mampu berinovasi. Proses pembelajaran yang terjadi di sekolah yang sarana prasarana memadai akan berjalan dengan efektif jika guru bisa memanfaatkan sarana yang ada. Tetapi untuk sekolah yang sarana prasarana tidak memadai, guru dituntut harus kreatif dan inovatif supaya tujuan dari pembelajaran bisa tercapai dengan semestinya.

Pembelajaran di abad 21, guru dituntut mampu menggunakan dan memanfaatkan teknologi digital. Dengan kemudahan informasi, diharapkan seorang dapat mencari informasi dengan mudah dan dapat mengolahnya menjadi media pembelajaran yang kreatif sehingga memotivasi siswa untuk dapat belajar dengan maksimal dan mencapai kompetensi yang telah ditentukan. Dengan keberagaman media yang digunakan proses belajar mengajar bisa dilakukan dengan menyenangkan. Karena melihat beragamnya karakteristik siswa dalam memperoleh informasi yang disampaikan oleh guru pada proses pembelajaran.

\section{Persepsi mahasiswa terhadap pembelajaran berbasis proyek pada mata kuliah media pembelajaran}

Berdasarkan data yang diperoleh dari hasil kusioner, kemudian ditabulasi dan di deskripsikan. Hasil persepsi mahasiswa terhadap pembelajaran berbasis proyek untuk setiap indikator pada mata kuliah media pembelajaran adalah:

a. Interaksi mahasiswa dan dosen

Berdasarkan skor yang diperoleh dengan menggunakan rumus derajat pencapaian (DP). Perhitungan untuk indikator interaksi mahasiswa dan dosen diperoleh skor $82,53 \%$, maka dapat disimpulkan interaksi mahasiswa dan dosen pada pembelajaran berbasis proyek pada mata kuliah media pembelajaran berada pada kategori baik.

b. Minat belajar mahasiswa

Berdasarkan skor yang diperoleh dengan menggunakan derajat pencapaian (DP). Perhitungan untuk indikator minat belajar siswa adalah 80,66\%, maka dapat disimpulkan minat belajar mahasiswa menggunakan pembelajaran berbasis proyek berada pada kategori baik

c. Kompetensi memahami materi ajar

Berdasarkan skor yang diperoleh dengan menggunakan rumus derajat pencapaian (DP). Perhitungan untuk indikator memahami materi ajar diperoleh skor $88,53 \%$, maka dapat disimpulkan mahasiswa dalam memahami materi ajar pada pembelajaran berbasis proyek berada pada kategori baik.

d. Kompetensi berfikir kritis, efektif dan efesien

Berdasarkan skor yang diperoleh dengan menggunakan rumus derajat pencapaian (DP). Perhitungan untuk indikator berfikir kritis, efektif dan efesien diperoleh skor $88,66 \%$, maka dapat disimpulkan mahasiswa mampu berfikir kritis, efektif dan efesien pada pembelajaran berbasis proyek berada pada kategori baik.

e. Kompetensi manajemen waktu

Berdasarkan skor yang diperoleh dengan menggunakan rumus derajat pencapaian (DP). Perhitungan untuk indikator manajemen waktu diperoleh skor 80,26\%, maka dapat disimpulkan interaksi manajemen waktu pada pembelajaran berbasis proyek berada pada kategori baik.

f. Hasil belajar mahasiswa 
Berdasarkan skor yang diperoleh dengan menggunakan rumus derajat pencapaian (DP). Perhitungan untuk indikator hasil belajar mahasiswa diperoleh skor $88,40 \%$, maka dapat disimpulkan interaksi hasil belajar mahasiswapada pembelajaran berbasis proyek berada pada kategori baik.

g. Kesesuaian penerapan pembelajaran berbasis proyek dengan karakteristik mata kuliah

Berdasarkan skor yang diperoleh dengan menggunakan rumus derajat pencapaian (DP). Perhitungan untuk indikator Kesesuaian penerapan pembelajaran berbasis proyek dengan karakteristik mata kuliah diperoleh skor 91,20\%, maka dapat disimpulkan Kesesuaian penerapan pembelajaran berbasis proyek dengan karakteristik mata kuliah pada pembelajaran berbasis proyek berada pada kategori sangat baik.

Efendi (2015) mengatakan bahwa terdapat hubungan yang signifikan antara persepsi siswa (mahasiswa) terhadap penerapan model pembelajaran dengan prestasi belajar. Persepsi yang baik tentang penerapan sebuah model pembelajaran mempunyai hubungan terhadap prestasi belajar. Namun perlu pembiasaan dalam pembelajaran.

\section{SIMPULAN}

Berdasarkan hasil penelitian diatas, simpulan dalam penelitian ini adalah sebagai berikut:

1. Salah satu bentuk kegiatan mata kuliah media pembelajaran dengan menggunakan model pembelajaran berbasis proyek adalah pembuatan media belajar visual, audio visual dan multimedia dengan tahapan, perancangan media belajar mulai dari menganalisis kompetensi dasar pada satu mata pelajaran. Kemudian membuat kerangka media pembelajaran, membuat hasil rancangan, dan terakhir mempresentasikan cara menggunakan media pembelajaran serta mempublikasikan ke google classroom.
2. Persepsi mahasiswa terhadap pembelajaran berbasis proyek pada mata kuliah media pembelajaran adalah baik dan sangat baik.

\section{DAFTAR PUSTAKA}

Ali, M. (2009). Pengembangan Media Pembelajaran Interaktif Mata Kuliah Medan Elekromagnetik. Pekanbaru: UIR

Allanasir. (2016). Pengaruh Penggunaan Media Animasi dalam Pembelajaran IPS terhadap Motivasi Belajar Siswa kelas IV SD Negeri Mannuruki. Journal of Educational Science and Technology (EST), 2(2), 81-90.

Asyhar, R. (2011). Kreatif Mengembangkan Media Pembelajaran. Jakarta: Gaung Persada Press.

Baidowi, A., Sumarni, S., and Amirudin, A. (tt) "Pengaruh model pembelajaran berbasis proyek terhadap kemampuan menulis karya ilmiah geografi siswa sma". Jurnal Pendidikan

Depdiknas. (2003). Undang-undang RI No.20 tahun 2003 tentang sistem pendidikan nasional. Jakarta: Depdiknas.

Effendi, E. (2015). Hubungan persepsi siswa terhadap penerapan model pembelajaran kooperatif tipe tutor sebaya dengan prestasi belajar fisika. Jurnal Pendidikan Fisika Universtas Muhammadiyah Metro, 3 (2), 14-24.

Hutasuhut, S. (2010). Implementasi Pembelajaran Berbasis Proyek (Project Based Learning) Untuk Meningkatkan Motivasi Dan Hasil Belajar Mata Kuliah Pengantar Ekonomi Pembangunan Pada Jurusan Manajemen Fe Unimed. Pekbis Jurnal, 2(1), 1-9.

Karina, N. K. D., Sadia, I. W., and Suastra, I. W. (2014). Pengaruh model pembelajaran berbasis proyek terhadap kemampuan pemecahan masalah dan kecerdasan emosionalsiswa smp. E-Journal Program Pascasarjana Universitas Pendidikan Ganesha, 4, 1-10.

Lubis, S. (2011). Metodologi Penelitian Pendidikan. Padang: Sukabina Press 
Made, W. (2014). Strategi Pembelajaran Inovatif Kontemporer. Jakarta : PT Bumi Aksara.

Sugiyono. (2008). Metode Penelitian Kuantitatif Kualitatif dan R\&D. Bandung : ALFABETA.

Tirtarahardja, U., \& Sulo, S. L. L. (2005). Pengantar Pendidikan Cetakan ke II. Jakarta: Rineka Cipta. 